\title{
ANALISIS PERUBAHAN STRUKTUR LEMBAGA NEGARA DAN SISTIM PENYELENGGARAAN KEKUASAAN NEGARA REPUBLIK INDONESIA BERDASARKAN UNDANG-UNDANG DASAR 1945 SEBELUM DAN SESUDAH AMANDEMEN
}

\author{
H. ISMAIL MZ \\ Fakultas Hukum Univ. Nahdatul Wathan Mataram \\ e-mail : Ismail2011958@yahoo.com
}

\section{ABSTRAK}

Perubahan UUD 1945 pasca reformasi 1998 didasarkan atas pengalaman praktik penyelengaraan ketatanegaraan oleh pemerintahan orde lama dan orde baru yang sering disebut sebagai sistim pemerintahan otoriter, baik secara terang-terangan maupun terselubung. UUD 1945 memang memberikan kekuasaan yang sangat besar kepada Presiden, baik Soekarno maupun Soeharto. Kelemahan-kelemahan yang terdapat dalam UUD 1945 itulah yang menjadi pemicu lahirnya tuntutan kaum reformis untuk dilakukannya amandemen terhadap UUD 1945 terutama yang menyangkut kekuasaan dan masa jabatan Presiden yang tak terbatas. Perlu disadari bahwa setelah UUD 1945 diamandemen, membawa implikasi yang sangat mendasar terhadap struktur ketatanegaraan Republik Indonesia. Sebelum perubahan UUD 1945 lembaga-lembaga negara yang ada adalah Majelis Permusyawaratan Rakyat, President, Dewan Perwakilan Rakyat, Dewan Pertimbanagan Agung, Badan Pemeriksa Keuangan dan Mahkamah Agung, yang sebutannyapun dibagi menjadi dua yaitu lembaga tertinggi negara yang disematkan pada lembaga Majelis Permusyawaratan Rakyat, dan yang lainnya berstatus sebagai lembaga tinggi negara biasa.

Setelah dilakukan perubahan atau amandemen terhadap UUD 1945 dari tahun 1999 sampai dengan tahun 2002 membawa implikasi terhadap perubahan struktur lembaga- lembaga negara yang ada dan jumlahnya menjadi lebih banyak jika dibandingkan dengan sebelum perubahan. Lemabaga negara setelah perubahan ada yang nomenklaturnya disebutkan secara eksplsit seperti lembaga : Majelis Permusyawaratan Rakyat, Dewan Perwakilan Rakyat, Dewan Perwakilan Daerah, Dewan Perwakilan Rakyat Daerah, Presiden dan Wakil Presiden, Menteri ( Khusus Menteri Dalam Negeri, Menteri Luar Negeri dan Menteri Pertahanan ) Gubernur, Bupati, Walikota, Tentara Nasional Indonesia, Kepolisian Negara Republik Indonesia, Mahkamah Agung, Mahkamah Konstitusi, Komisi Yudisial Dan Badan Pemeriksa Keuangan. Sementara ada lembaga negara lainnya yang nomenklaturnya tidak disebutkan secara eksplisit adalah Dewan Pertimbangan, Komisi Pemilihan Umum dan Bank Sentral. Sebagai konskuensi dari perubahan UUD 1945 adalah sistim ketatanegaraan yang dianut juga berubah, Jika sebelum perubahan sistim ketatanegaraan yang dianut adalah sistim perwakilan uni cameral, tapi setelah perubahan menjadi sistim bicameral bahkan ada yang menyebutnya tri kameral.

Kata Kunci : Amandemen, perubahan struktur, lembaga negara.

\section{ABSTRACT}

The amendment to the 1945 Constitution after the 1998 reform is based on the experience of the practice of state administration by the old and new order governments which are often referred to as authoritarian government systems, both overt and covert. The 1945 Constitution indeed gives enormous power to the President, both Sukarno and Suharto. Weaknesses contained in the 1945 Constitution that triggers the birth of the demands of the reformists to make amendments to the 1945 Constitution, especially concerning the power and term of office of the President. It is important to realize that after the 1945 Constitution is amended, it has very basic implications for the structure of the Republic of Indonesia. Before the amendment to the 1945 Constitution the existing state institutions are the People's Consultative Assembly, the President, the People's Representative Council, the Supreme Consultative Council, the Supreme Audit Board and the Supreme Court, whose titles are divided into two, namely the highest state institutions which are embedded in the People's Consultative Assembly, and the other is a high-level state institution. 
After changes or amendments to the 1945 Constitution from 1999 to 2002 have implications for changes in the structure of existing state institutions and the number becomes more than before the change. The state institutions after the change are explicitly mentioned in the nomenclature such as: the People's Consultative Assembly, the House of Representatives, the Regional Representative Council, the Regional People's Representative Council, the President and Vice President, the Minister (Specially the Minister of the Interior, the Minister of Foreign Affairs and the Minister of Defense) Governor, Regent, Mayor, Indonesian National Army, Republic of Indonesia National Police, Supreme Court, Constitutional Court, Judicial Commission and Supreme Audit Board. While there are other state institutions whose nomenclature is not mentioned explicitly namely; Advisory Council, Election Commission and Central Bank. As a consequence of the amendment to the 1945 Constitution, the constitutional system adopted has also changed. If before the change to the constitutional system adopted is the cameral union representative system, but after the change into the bicameral system, some even called it tri kameral.

Keywords: Amendments, changes in structure, state institutions.

\section{PENDAHULUAN}

\section{Latar Belakang}

Era Reformasi memberikan harapan segar dan besar untuk mengadakan perubahan dalam sistim penyelengaraan negara dan pemerintahan, agar dapat mewujudkan negara Indonesia menjadi negara konstitisional, negara hukum dan negara demokrasi. Hal ini sejalan dengan apa yang menjadi harapan dan tuntutan kaum reformis dari berbagai elemen masyarakat dengan sasaran akhir adalah tercapainya tujuan negara dan cita-cita kemerdekaan sebagaimana yang tercantum dalam pembukaan UUD 1945. Beberapa tuntutan reformasi tahun 1998, salah satu diantaranya adalah melakukan perubahan terhadap UUD 1945. Tuntutan ini mempunyai landasan pemikiran teoritis konseptual dan pertimbangan empiris, selama peraktik penyelenggaraan ketatanegaraan Indonesia yang sudah berjalan selama lebih dari setengah abad ketika reformasi bergulir.

Kelemahan-kelemahan yang terdapat dalam UUD 1945 sebelum diamandemen secara konseptual memang membuka peluang bagi seorang Presiden untuk berkuasa secara otoriter, karena penyelenggaraan negara dan pemerintahan berlawanan dengan arah dari azas kedaulatan rakyat, azas negara hukum dan azas demokrasi, dan ditambah lagi dengan dinamika sosial, politik dan ekonomi yang dikembangkan bertentangan dengan konsep dasar yang diamanatkan dalam UUD 1945. Dalam praktik penyelengaraan kekuasaan negara dan pemerintahan terjadi ketidak seimbangan, karena tidak mencerminkan mekanisme sistim cheks and balances antar lembaga negara yang ada saat itu. Dengan dilakukannya perubahan terhadap UUD 1945 telah membawa implikasi yang sangat mendasar terhadap struktur kekuasaan negara dan praktik penyelenggraan ketatanegaraan Indonesia, terutama yang berkaitan dengan kekuasaan Presiden. Salah satu bebtuk perubahannya adalah terjadi pergeseran kekuasaan dari ekskutif ( exskutive heavy) kelembaga legislative ( legistive heavy).

Ketentuan UUD 1945 sebelum perubahan, pasal-pasalnya mengadung pemahaman dan penafsiran yang sangat luas dan fleksibel, sehingga berakibat multi tafsir. Misalnya Pasal 7 UUD 1945 sebelum amandemen berbunyi : "Presiden dan Wakil Presiden memegang jabatan selama lima tahun dan sesudahnya dapat dipilih kembali”. Berdasarkan ketentuan pasal ini, tidak ada batasan masa jabatan Presiden dan Wakil Presiden, asal masih dipilih oleh MPR beberapa kalipun tidak masalah. Buktinya Presiden Soeharto berhasil menduduki jabatan Presiden selama 32 tahun, sementara untuk Wakil Presiden selalu berganti-ganti (Ni'matul Huda, 2006 : 137).

Pada era ketika rezim Orde Baru masih berkuasa, masyarakat dibodohin dengan mengatakan kalau UUD 1945 negara akan kacau balau bahkan akan hancur, bahkan kalau ada gagasan untuk merubah UUD 1945 dianggap sebagai tindakan Subversif dan Korbannya antara lain Sri Bintang Pamungkas, karena berani menawarkan RUUD RI sebagai Pengganti UUD 1945 yang sedang dijalankan oleh Penguasa rezim Orde Baru.

Pembatasan kekuasaan Presiden ini didasarkan atas pengalaman sejarah, dimana selama dua fase pemerintahan sebelumnya yakni pemerintahan Presiden Soekarno dan Presiden Soeharto. Sebagai akibat dari kekuasaan Presiden yang terlalu besar dan dominan yang diberikan oleh UUD 1945 sebelum perubahan menjadikan demokrasi terbelenggu, sehingga Presiden dalam menjalankan kekuasaanya cendrung otoriter dan refresif. Atas dasar itulah, maka ketika ada momentum perubahan konstitusi dibuka ruang yang diawal reformasi, 1998 maka, pendulum kekuasaan digeser dari lembaga ekskutif ke lembaga legislative. Setelah 
perubahan keempat UUD 1945 tahun 2002, Indonesia memasuki babak baru pelaksanaan UUD 1945 hasil perubahan.

UUD 1945 sebagai landasan dasar dalam mengatur dan menentukan organisasi dan struktur ketatanegaraan, pasca perubahan, beberapa lembaga negara juga berubah, demikian pula dengan hubungan antar lembaga negara, lahir lembaga baru dan ada penghapusan lembaga negara yang sudah ada seblumnya. Penambahan lembaga negara yang baru pasca amandemen antara lain Mahkamah Konstitusi ( MK ), Komisi Yudisial ( KY ) dan Dewan Perwakilan Daerah ( DPD ). Sedangkan lembaga negara yang sudah ada dihapuskan adalah Dewan Pertimbangan Agung ( DPA ). Lahirnya lembaga Mahkamah Konstitusi ( MK ) meruapak lembaga yang menyelenggarakan kekuasaan kehakiman, disampin Mahkamah Agung ( MA ). Sementara Komisi Yudisial ( KY ) diberikan kewenangan untuk menjaga keluhuran martabat, kehormatan hakim dan hakim agung.

Salah satu fenomena penting pasca perubahan UUD 1945 adalah banyaknya lembaga-lembaga baru yang dibentuk berdasarkan UUD 1945 hasil perubahan maupun yang dibentuk berdasarkan Undang-Undang. Adanya pembentukan lembaga negara dengan dasar hukum yang berbeda menunjukkan bahwa ada lembaga negara yang dibentuk berdasarkan pertimbangan issue-isue parsial, incidental yang dinilai dapat memberikan jawaban atas persoalan-persoalan negara yang sedang dihadapi. Pertimbangan lain sebagai dasar pembetukan lemabaga baru berdasarkan Undang-Undang adalah Karena lembaga negara yang sudah ada belum dapat menyelesaikan persoalan yang timbul, sementara tuntutan masyarakat akan pelayanan public yang cepat dan lebih baik terus meningkat dengan cepat dan dinamis. Hal ini bisa menjadi indikasi bahwa kepercayaan masyarakat menurun terhadap lembaga negara yang sudah ada karena tidak mampu menyelesaiakan berbagai persoalan kenegaraan yang dihadapi (T.M. Lutfi Yazid, dalam Yarsif Watampone ,2004: 2)

Lemabaga negara di Indonesia yang menurut Hans Kelsen menyebutnya sebagai Organ Negara itu setidak-tidaknya menjalankan salah satu dari dua fungsi yakni Pertama : Menciptakan Hukum ( Law Creating Function ); Kedua : Fungsi menerapkan atau menjalankan hukum ( Law applying function ).

Berdasarkan argument Hans Kelsen tersebut, Jimly Asshiddiqie (2006), menyimpulkan bahwa pasca amandemen UUD 1945, dibentuklah 34 lembaga negara. Dari 34 lembaga negara ini, 28 lembaga negara kewenangannya baik umum maupun rinci ditentukan berdasarkan UUD 1945. Lembaga negara yang ke 28 inilah yang disebut sebagai lembaga negara yang memiliki kewenangan konstitusional yang diberikan oleh UUD 1945 pasca perubahan. Dengan semakin banyaknya lembaga negara yang muncul, menimbulkan pertanyaan, apakah semua lembaga negara yang disebutkan dalam UUD 1945 pasca amandemen tersebut adalah lembaga negara ?. Untuk menjawab persoalan tersebut, perlu dilakukan analisis tentang konsep lembaga negara. Berdasarkan analisis itu baru dapat diklasifikasikan lembaga-lembaga negara yang mana masuk dalam kategori lembaga negara dan mana yang bukan lembaga negara.

Dari urian di atas, telah disebutkan ada 34 lembaga negara, dapat diklasifikasi dari dua segi yakni segi fungsinya dan dari segi hirarhinya. Hirarhi ini penting dilakukan untuk menentukan perlakuan hukum terhadap orang yang menduduki jabatan dalam lembaga negara itu, mana yang lebih tinggi dan mana yang rendah, karena ini ada kaitannya dengan penentuan posisi letak duduknya dalam suatu upacara kenegaraan yang resmi serta untuk penentuan besaran tunjangan jabatannya. Untuk itu ada dua criteria yang dipergunakan yakni Pertama : Kriteria hirarhi normative untuk menentukan kewenangannya. Kedua : Kriteria Kualitas Fungsinya. Kualitas fungsi ini dibedakan menjadi yaitu Fungsi Utama atau primer dan Fungsi Penunjang atau skunder. Sedangkan dari segi hirarhinya lembaga negara itu dapat dibedakan menjadi tiga lapis yakni : Lapis pertama disebut lembaga tinggi negara, Lapis kedua disebut lembaga negara saja, dan lapis ketiga merupakan lembaga yang ada di daerah.

Bertolak dari uraian diatas, ternyata di Indonesia tidak banyak literature yang membahas tentang pengertian lembaga negara. Setiap tulisan yang membahas prihal lembaga negara berdasarkan UUD 1945 langsung menujuk pada Ketetapan MPR No.III/MPR/1978. Pembahasan mengenai konsep lembaga negara baru dapat ditemui dalam tulisan beberapa orang Hakim Konstitusi. HAS, Natabaya menulis tentang lembaga tinggi negara menurut menurut UUD 1945 dalam buku Menjaga Denyut Konstitusi, Refleksi Satu Tahun Mahkamah Konstitusi. Menurut HAS Natabaya bahwa istilah badan, organ, atau lembaga mempunyai makna yang esensinya kurang lebih sama. Ketiga istilah itu dapat digunakan untuk menyebut suatu orgaanisasi yang tugas dan fungsinya menyelenggarakan pemerintahan negara. Namun yang perlu ditekankan menurut Natabaya adalah konsistensi penggunaan istilah, agar tidak digunakan dua istilah untuk maksud yang sama.

Dari sekian banyak lembaga negara yang disebutkan dalam UUD 1945 pasca amandemen, kekuasaan Presiden masih dalam posisi yang kuat. Karena itu dalam penyelenggaraan tugas kenegaraan dan pemerintahan, maka sistim makanisme cheks and balances harus dikembangkan, sehingga tercipta 
keseimbangan. Untuk membatasi kekuasaan Presiden yang kedudukannya sangat kuat dalam sistim Presidensiil sesuai dengan kebutuhan agar stabilitas pemerintahan terjamin, maka masa jabatan Presiden dibatasi selama lima tahunan dan tidak boleh dijabat oleh orang yang sama lebih dari dua priode masa jabatan. Selain itu beberapa lembaga negara yang masuk lingkungan cabang ekskutif ditentukan independensinya dalam menjalankan tugas utamanya. Lembaga-lembaga dimaksud antara lain Bank Indonesia sebagai bank sentral, Kepolisian Negara, Kejaksaan Agung, sebagai aparat penegak hukum, Tentara Nasional Indonesia sebagai aparatur petahanan negara. Apabila Presiden ingin mengangkat dan memberhentikan Gubernur BI, Kapolri, Jaksa Agung dan Panglima TNI harus dengan persetujuan DPR.

Jika sebelum amandemen UUD 1945 kekuasaan legislasi menjadi kewenangan Presiden dan DPR, tapi setelah amandemen Kekuasaan legislasi perpindah ke DPR dan DPD untuk hal-hal tertentu dan terbatas. Atas dasar pemikiran diatas penulis tertarik untuk menganalisis tentang Struktur Lembaga negara dan sistim penyelenggaraan kekuasaan negara Republik Indonesia sebelum dan sesudah amandemen UUD 1945. Berdasarkan uraian diatas, maka dalam tulisan ini akan dianalisis perubahan struktur lembaga negara dan sistim penyelenggraan kekuasaan negara sebelum dan sesudah perubahan UUD 1945.

\section{Rumusan Masalah}

Dari uraian sebelumnya maka dalam tulisan ini dapar dirumuskan permasalahan sebagai nerikut :

1. Bagaimana struktur lembaga negara dan sistim penyelenggaraan kekuasaan negara Republik Indonesia sebelum dan sesudah amandemen UUD 1945 ?

2. Bagaimana hubungan kerja antar lembaga negara dalam rangka menciptakan keseimbangan ( cheks and balances ) pasca amandemen UUD 1945 ?

\section{METODE PENELITIAN}

Penelitian ini menggunakan metoda pendekatan Yuridis Normatif, artinya analisis ini berangkat dari ketentuan normative yang diatur dalam UUD 1945. Selain itu dalam analisis ini penulis memakai pendekatan teoritis, apakah ketentuan yang ditetapkan dalam UUD 1945 itu sudah sesuai atau tidak dengan teori-teori yang terakit langsung dengan perubahan struktur kelembagaan negara dan sistim penyelengaraan kekuasaan negara pasca amandemen UUD 1945, dalam hubungannya dengan praktik penyelenggaraan kekuasaan negara dan pemerintahan di Indonesia.

\section{PEMBAHASAN}

\section{Struktur Lembaga Negara dan Sistem Penyelenggaraan Kekuasaan Negara Republik Indonesia Sebeum dan Sesudah Amendemen UUD 1945}

Undang-undang Dasar 1945 yang merupakan hukum dasar dan sebagai landasar dalam menetapkan dan mengatur organisasi negara Indonesia, sehingga memberikan jaminan legitimasi terhadap keberadaan lembaga negara itu. Prinsip dasar dan konsep bernegara yang dianut dalam pembukaan UUD 1945 belum mencerminkan secara jelas dalam pasal-pasal UUD 1945, sehingga hal ini memberikan peluang untuk menafsirkan ketentuan dalam pasal-pasal tersebut untuk ditafsirkan menurut kemauan penyelenggara negara. Hal ini terbukti pada dua fase kepemimpinan negara pada rezim Orda Lama dengan Presiden Soekarno dan Rezim Orde Baru dengan Presiden Soeharto. Kekuasaan lembaga negara yang ada tidak berimbang, tidak ada mekanisme cheks and balances antar lembaga negara. Bahkan ada penyelenggaraan negara dan pemerintahan yang meyimpang dari sistim yang ditetapkan dalam UUD 1945.

MPR sebelum reformasi telah menetapkan sikap tidak akan merubah UUD 1945, akan tetapi setelah reformasi karena derasnya tuntutan masyarakat, ternyata MPR telah mencabut pernyataan-pernyataan politiknya yang telah ditetapkan dalam berbagai produk hukum. MPR telah empat kali melakukan perubahan UUD 1945. Bahkan MPR telah mencabut kekuasaannya sendiri dengan merubah kedudukan MPR dari lembaga tertinggi negara mejadi lembaga tinggi negara, sejajar dengan lembaga negara lainnya. Perubahan UUD 1945 sampai dengan keempat kalinya telah merubah sistim ketatanegaraan Indonesia secara mendasar, baik yang menyangkut sistim pemerintahan, sistim perwakilan dan pelaksanaan yudisial. Sistim pemilihan Presiden juga ikut berubah dari sistim perwakilan melalui MPR menjadi pemilihan langsung. Demikian juga dengan sistim perwakilan, yang semula hanya ada DPR, lahir lembaga perwakilan baru yakni DPD, sehingga 
lembaga perwakilan menjadi dua kamar ( DPR dan DPD ). Selain DPD pada saat yang sama juga lahir lembaga baru yaitu Mahkamah Konstitusi.

Dari hasil kajian meskipun UUD 1945 sudah mengalami perubahan sebanyak empat kali, namun masih banyak ditemukan kelemahan, baik dari segi substansi maupun dari segi prosuduralnya. Salah satu kelemahan yang sering dijadikan topic diskusi diruang public adalah mengenai keberadaan lembaga DPD yang masih sangat jauh dari konsep bicameral, bahkan ada yang mengatakan bukan dua cameral, tapi trikameral. Dalam Pasal 1 ayat ( 2 ) UUD 1945 pasca amandemen menetapkan bahwa kedaulatan berada ditangan rakyat dan dilaksanakan menurut Undang-Undang. Terhadap ketentuan ini perlu kajian lebih lanjut, karena sampai dengan saat ini masih belum jelas bagimana model pelaksanaan kedaulatan rakyat menurut UUD tersebut, kemudian bagaimana mekanisme hubungan kerja antara MPR, DPR dan DPR yang nota bene diklaim sebagai lembaga perwakilan rakyat.

Sebelum UUD 1945 diamandemen, banyak pihak mengatakan bahwa ketentuan dalam pasal-pasalnya sering menimbulkan multi tafsir. Idealnya UUD 1945 hasil amandemen seharusnya menjadi lebih baik, ketimbang praktik penyelenggaraan ketatanegaraan ketika UUD 1945 sebelum diamandemen. Rumusan yang dimuat dalam UUD 1945 tentang semangat penyelenggraan negara belum mencerminkan sistim pemerintahan yang demokratis, hal ini dibuktikan dengan antara lain

a. UUD 1945 dianggap sakral dan tidak boleh dirubah, kalau UUD 1945 dirubah, negara akan kacau balau, bahkan menyampaikan gagasan perubahan saja dianggap sebagai tindakan subversif.

b. Kekuasaan terpusat pada Presiden, sehingga tidak ada mekanisme cheks and balances antar lembaga terutama DPR;

c. Infrastruktur politik seperti partai politik dan masyarakat tidak memiliki kebebasan, sehingga partai politik tidak dapat menjalankan fungsinya sebagaimana mestinya;

d. Pelaksanaan pemilihan umum, sifatnya formalitas sekedar untuk memenuhi persyaratan demokrasi formal, karena seluruh proses dan tahapan pemilu dilaksanakan dan dikuasai oleh pemerintah.

e. Kesejahteraan rakyat sesuai amanat pasal 33 UUD 1945 tidak pernah tercapai, justru yang berkembang adalah sistim monopoli dan oligarsi.

UUD 1945 perubahannya dilakukan oleh MPR hasil pemilu tahun 1999, yang diikuti oleh partai politik lama maupun baru, sehingga tidak menghailkan pemenang pemilu dengan kekuatan mayoritas. Akibat dari kondisi ini menyebabkan terjadi kompromi politik saat dilakukannya perumusan pasal-pasal perubahan. Jika hal ini kita kaji dari sudut pandang Ilmu Hukum Tata Negara, tidak mudah untuk dipahami. Proses persiapan perubahan dilakukan oleh patia Adhok BP MPR, yang anggota-anggotanya mencerminkan kekuatan fraksifraksi partai politik yang ada di DPR. Dengan demikian, kesepakatan yang diambil oleh panitia Adhok Badan Pekerja MPR pada saat merumuskan pasal-pasal perubahan UUD 1945 adalah sebagai berikut :

a. Panitia sepakat untuk tidak merubah Pembukaan UUD 1945, Sistimatika, aspek kesejarahan dan keasliannya;

b. Sepakat untuk tetap mempertahankan bentuk negara kesatuan ( NKRI );

c. Mempertahankan sistim pemerintahan Presidensial;

d. Penjelasan UUD 1945 ditiadakan dan hal-hal yang bersifat normative dalam penjelasan dimasukkan dalam pasal-pasal perubahan;

e. Perubahan dilakukan secara addendum, artinya tidak menghilangkan pasal-pasal aslinya atau dikenal dengan istilah tambal sulam.

Dari empat kali perubahan dalam bentuk penambahan dan penghapusan ayat-ayat yang dinilai sudah tidak relevan dengan kebutuhan ketatanegaraan Indonesia. Secara keseluruhan UUD 1945 yang diamandemen terdiri dari 73 pasal. Komposisinya yang semula terdiri atas Pembukaan, Batang Tubuh dan Penjelasannya berubah menjadi hanya terdiri dari Pembukaan dan pasal-pasalnya saja.

\section{Lembaga Negara dan Sistem Penyelengaraan Kekuasaan Negara sebelum Amandemen UUD 1945}

Sebagaimana kita ketahui bersama bahwa UUD merupakan hukum dasar tertinggi dalam negara Republik Indonesia. Sesuai dengan ketentuan yang dimuat dalam UUD 1945 menegaskan bahwa kedaulatan rakyat diberikan seluruhnya kepada MPR sebagai lemabaga Tertinggi Negara. MPR Kemudian mendistribusikan kekuasaannya ( distribution of power ) kepada lembaga tinggi negara yang kedudukannya sejajar yakni : Dewan Perwakilan Rakyat ( DPR ), Presiden, Mahkamah Agung ( MA ), Dewan Pertimbangan Agung ( DPA ) dan Badan Pemeriksa Keuangan ( BPK ). Secara rinci lembaga-lembaga negara inilah yang seharusnya menjalankan kekuasaan penyelenggaraan negara dan pemerintahan. 


\section{Majelis Permusyawaratan Rakyat (MPR)}

a. Dalam kontek gelobal MPR dinamakan Unik, karena merupakan lembaga perwakilan tapi kedudukannya berada diatas Parlemen ( DPR ). MPR Sebagai lemabaga tertinggi negara diberikan kekuasaan tak terbatas ( Super Power ) karena kekuasaan ada di tangan rakyat dan dijalankan sepenuhnya oleh MPR, karena itu MPR dianggap sebagai penjelmaan seluruh rakyat Indonesia dengan kewenangannya adalah

1. Menetapkan UUD;

2. Menetapkan Garis-Garis Besar Haluan Negara ( GBHN );

3. Mengangkat Presiden dan Wakil Presiden.

b. Susunan keanggotaan MPR terdiri dari :

1. Anggota DPR;

2. Utusan Daerah;

3. Utusan Golongan yang diangkat ( Pen. Jumlah yang diangkat lebih banyak dari pada hasil pemilu).

Pada masa Orda Lama, MPR ini telah dijadikan sebagai alat politik oleh Presiden untuk memperkokoh ideology Manipol Usdek dan menyatakan Presiden Soekarno sebagai Presiden seumur hidup. DPR dipreteli dari berbagai kewenangan yang dimilki antara lain dari hak mengajukan usul angket dan usul mosi. Accountability boleh dikatakan tidak dilaksanakan, Akan tetapi pada ahir perjalanan kekuasaan Presiden Soekarno harus memberikan pertanggugjawaban kepada MPR. Hal inilah yang menyebabkan berakhirnya Jabatan Soekarno sebagai Presiden Republik Indonesia (Ni'matul Huda, 2006:153).

Kekuasaan yang besar dari MPR dalam praktik ketatanegaraan, tidak jarang diselewengkan atau dipergunakan sebagai alat politik untuk memperbesar kekuasaan Presiden yang meskipun jelas-jelas bertentanagan dengan UUD 1945, seperti pemberian kekuasaan tidak terbatas kepada Presiden selaku mandataris MPR dalam rangka menyuseskan dan pengamanan pembangunan nasional sebagai pengamalan Pancasila ( Tap. MPR No.V/MPR/1998 ). Selain itu MPR yang memilih Presiden secara berturut-turut semapai 7 kali dan MPR pula yang meminta Presiden untuk undur dari jabatannya sebagai akhir perjalanan rezim Orde Baru. Lembaga negara yang paling mungkin menandingi kekuasaan MPR adalah Presiden yaitu dengan memanfaatkan kekuatan fraksi partai politik yang paling dominan menduduki kursi MPR. Pada masa rezim kekuasaan Orde Baru jumlah anggota MPR yang diangkat jauh lebih besar dari jumlah hasil pemilihan umum, sehingga dengan demikian akan sangat mudah untuk mengarahkan mereka untuk meraih apa yang diinginkan oleh Presiden melalui anggota MPR yang diangkat dan sekaligus sebagai balas jasa kepada Presiden.

\section{Lembaga Kepresidenan}

Berdasarkan ketentuan UUD 1945 sebelum diamandemen, kekuasaan Presiden itu sangat besar dan dominan dibandingkan dengan kekuasaan lembaga negara yang lainnya. Kewenangan dan Kekuasaan Lembaga Kepresidenan antara lain :

a. Presiden memegang posisi sentral dan dominan, karena berperan ganda sebagai Kepala Negara dan Kepala Pemerintahan serta sekaligus sebagai Mandataris MPR;

b. Presiden menjalankan kekuasaan pemerintahan negara tertinggi. Presiden Soekarno pernah mengangkat seluruh anggota MPR tanpa melaui proses Pemilihan Umum. Sementara Presiden Soeharto pernah merekayasa undang-undang susunan dan kedudukan MPR, sehingga MPR tidak berdaya dalam mengawasi Presiden.

c. Presiden selain memegang kekuasaan ekskutif, juga memegang kekuasaan legislative dan yudikatif.

d. Presiden memilik hak prerogative yang sangat besar, terutama dalam menetapkan kebijakan yang menguntungkan dan memperkuat posisi Presiden.

e. Tidak ada aturan yang membatasi priode maja jabatan seorang Presiden, karena Pasal 7 UUD 1945 berbunyi : "Presiden dan Wakil Presiden memegang jabatan selama lima tahun, dan sesudahnya dapat dipilih kembali”. Penjelasan dalam pasal 7 dipandang sangat fleksibel untuk ditafsirkan. Bahkan Soeharto pernah mengatakan, tentang berapa kali sesorang dapat menjabat Presiden sangatlah tergantung pada MPR. Ia dapat terus menerus menjabat Presiden. Dan Soehartolah yang telah menikmati kebebasan menduduki Jabatan Presiden, karena ia sendiri yang boleh membuat tafsir dan menafsirkan sendiri atas UUD 1945. MPR hanya mengaminkan saja (Ni'matul Huda, 2006:187)

\section{Dewan Perwakilan Rakyat ( DPR )}

a. Memberikan persetujuan atas Rancangaan Undang-Undang yang diusulkan oleh Presiden;

b. Memberikan persetujuan atas Peraturan Pemerintah Pengganti Undang-Undang(PERPU); 
c. Memberikan persetujuan atas Anggaran;

d. Meminta MPR untuk mengadakan siding istimewa guna meminta pertanggungjawaban Presiden.

\section{Mahkamah Agung}

UUD 1945, menetukan bahwa kekuasaan kehakiman atau fungsi Yudikatif ( judicial) hanya terdiri atas badan-badan peradilan yang berpuncak pada MA. Lembaga MA sesuai dengan prinsip "independent of judiciary " bersifat mandiri dalam arti tidak boleh diintervensi atau dipegaruhi oleh cabang-cabng kekuasaan lainnya, untuk menyelenggarakan peradilan guna menegakkan hukum dan keadilan. Kemerdekaan dan kebebasan kekuasaan kehakiman dari pengaruh kekuasaan lainnya kekuasaan pemerintah. Prinsip kemerdekaan hakim ini selain diatur dalam Undang-undang pokok kekuasaan kehakiman yakni UU No. 14 Tahun 1970, sebagai bentuk pendelegasian pasal 24 UUD 1945. Sebelum amandemen UUD 1945 kekuasaan kehakiman belum sepenuhnya bebas dan merdeka. Hal ini disebabkan karena adanya pemisahan pengaturan teknis yudisial dan urusan organisasi, administrasi dan finasial para hakim. Kewenangan yudisial ada pada MA, sedangkan pengaturan organisasi, adminstrasi dan financial ada pada departemen terkait.

Konisi ini tentu akan menimbulkan dualism dalam pelaksanaan kekuasaan kehakiman yang bebas dab merdeka. Tidak jarang hakim merasa ketakutan untuk memberikan keputusan terhadap kasus-kasus yang terkait dengan pemerintah. Ketakutan itu disebabkan karena ditangan pemerintah Cq. Departemen terkait urusan perut para hakim diatur. Sehubungan dengan hal ini muncul wacana agar urusan Yudisial, organisasi, adminstrasi dan financial berada di satu isntitusi yaitu MA. Dengan demikian maka indepensi para hakim akan bisa terjaga dengan baik, tanpa harus takut dengan tekanan dari pihak lain.

\section{DPA dan BPK}

Peranan DPA, sebagai lembaga yang bertugas untuk memberikan usul, saran dan pertimbangan kepada Presiden jarang diminta, sehingga lembaga ini ada, tapi tiada. Oleh karena itu, pada saat UUD 1945 diamandemen, lembaga ini dianggap tidak diperlukan dan bahkan dihapus sebagai lembaga negara yang resmi. Demikian juga dengan peran BPK sebelum perubahan UUD 1945 tidak banyak yang mengintrodusir lembaga ini, karena memang diberikan kewenangan yang sangat terbatas.

\section{Struktur Lembaga Negara dan Sistem Penyelenggaraan Kekuasaan Negara Pasca Amandemen UUD 1945}

UUD suatu negara tetap berperan sebagai hukum dasar tertinggi, untuk mengatur pembagian kekuasaan kepada lembaga-lemabaga negara yang ada yang dibentuk berdasarkan UUD itu sendiri. Sesuai ketentuan UUD 1945 membagi kekuasaan kepada 7 lembaga negara dengan kedudukan yang sama dan sederajat yaitu Majelis Permusyawaratan Rakyat ( MPR ), Dewan Perwakilan Rakyat ( DPR ), Dewan Perwakilan Daerah ( DPD ), Presiden, Mahmakah Aagung ( MA ), Mahkamah Konstitusi ( MK ), dan Badan Pemeriksa Keuangan.

Setelah amandemen UUD 1945 ada beberapa hal yang prinsip dan mendasar yang dipakai sebagai dasar pemikiran dalam menata struktur lembaga negara dan penyelenggaraan kekuasaan lembaga negara agar tetap berada dalam koridor konstitusi antara lain :

a. Sistim konstitusi menghendaki adanya keseimbangan dalam menjalankan kekuasaan dari masing-masing lembaga negara ( cheks and balances ) sehingga setiap kekuasaan dibatasi oleh Undang- Undang sesuai dengan fungsi dan kewenangan masing-masing lembaga;

b. Setiap lembaga negara mempunyai kedudukan yang sama dan sejajar dibawah UUD 1945;

c. Menata kembali lembaga negara yang sudah ada sebelumnya dan membentuk lembaga baru agar sesuai dengan perkembangan sistim ketatanegaraan yang konstitusional dan prinsip negara demokrasi dan negara hukum.

d. Penyempurnaan kedudukan dan kewenangan masing-masing lembaga negara yang disesuaikan dengan perkembangan negara demokrasi.

\section{Majelis Permusyawaratan Rakyat (MPR)}

a. Kedudukan lembaga MPR sejajar dengan lembaga negara lainnya seperti DPR, DPD, Presiden, MA, MK dan BPK; 
b. Supremasi Kewenangan MPR sudah dihilangkan, bukan lagi sebagai lembaga super power seperti sebelum UUD 1945 yang belum diamandemen;

c. Kewenangan menetapkan kewenangan GBHN dihilangkan;

d. Tidak lagi berwenang mengangkat Presiden dan Wakil Presiden, karena Persiden dan Wakil Presiden sudah dipilih langsung oleh rakyat dalam satu paket pemilihan umum;

e. Kewengan masih tetap bertahan adalah mengubah dan menetapkan UUD;

f. Komposisi Susunan keanggotaan MPR sudah berubah yakni terdiri anggota DPR dan DPD yang dipilih secara langsung oleh rakyat melalui pemilihan umum, anggota yang diangkat tanpa pemilu sudah tidak ada lagi.

\section{Dewan Perwakilan Rakyat ( DPR )}

Pasca Amandemen UUD 1945 posisi DPR semakin diperbuat, karena sebagian tugas yang sebelum UUD 1945 diamandemen berada di ditangan Presiden, beralih ke DPR.

a. Kekuasaan membentuk UU ada pada lembaga DPR, sementara Presiden hanya memiliki hak mengajukan rancangan undang-undang. Pemberdayaan DPR bukannya DPR lebih kuat dibanding dengan Presiden, karena kedua lembaga negara ini keudukannya sama dan sejajar. Secara factual, dengan sistim pemerintahan presidensial, posisi Presiden tetap masih kuat karena masih ada hak prerogatifnya, meskipun sebagian kekuasaannya telah banyak dikurangi pasca amandemen UUD 1945;

b. Proses dan mekanisme membentuk UU antara DPR dan Pemerintah dibahas dan disetujui bersama;

c. Semakin mempertegas fungsi DPR yakni : Fungsi Legislasi, Fungsi anggarat ( Budget ) dan Fungsi Pengawasan sebagai mekanisme cheks and balances antar lembaga negara.

\section{Dewan Perwakilan Daerah (DPD)}

Keberadaan DPD menurut ketentuan UUD 1945 pasca perubahan banyak dikritik orang. Lembaga ini sejak awal didesain sebagai kamar parlemen kedua Indonesia dimasa depan. Salah satu ciri bicameral yang dikenal di dunia adalah apabila kedua kamar dimaksud dapat menjalankan fungsi legeslatif sebagaimana mestinya. Dengan demikian lembaga DPD dapat dikatakan soft bilameral, karena bika dicermati DPD tidak memiliki kekuasaan apapun sebagai bagian dari lembaga perwakilan dan tidak ada keseimbangan tugas poko dan fungsinya bila disandingkan dengan DPR. DPD hanya diminta memberikan masukan, usul dan saran, sementara yang berhak memutuskan adalah DPR. Karena itu keberadaan DPD disamping DPR tidak bisa disebut sebagai bikameraalisme dalam arti yang lazin dan berlaku diberbagai negara yang menganut sistim perwakilan seperti AS dan Inggris.

Menurut ketentuan pasal 22 D ( a ) UUD 1945 DPD dapat mengajukan Rancangan UU tertentu kepada DPR. ( ayat 1, ( b ) Ikut membhas RUU tertentu ( ayat 1 ), ( c ). Memberikan petimbangan kepada DPR atas RUU APBN dan RUU tertentu ( ayat 2 ), ( d ) Dapat melakukan pengawasan atas pelaksanaan UU tertentu ( ayat 3). Dengan kata lain DPD memiliki fungsi sekedar memberikan masukan, usul, dan saram sedangkan yang memutuskan adalah DPR. Jika demikian fungsi yang diberikan kepada DPD, menurut penulis keberadaan DPD lebih tepat dikatakan sebagai Dewan Pertimbangan DPR, karena sepertri yang dijelaskan dalam pasal-pasal yang mengatur tentang peran dan fungsi DPR berkutat pada memberikan pertimbangan, masukan, usul dan saran kepada DPR.

Ironi memang, dimana pengisian jabatan anggota DPD jauh lebih berat bila dibandingkan dengan mekanisme pengisian anggota DPR. Setiap anggota DPD dari setiap Provinsi dipilih memalui pemilu, Anggota DPD tiap Provinsi jumlahnya sama, dan seluruh anggota DPD tidak boleh lebih dari $1 / 3$ dari jumlah anggota DPR. Jumlah anggota DPD tiap Provinsi 4 orang. Jika sesorang ingin menduduki jabatan DPD maka ia harus bersaing ketat ditingkat Provinsi untuk merebutkan 4 kursi. Contoh untuk Provinsi besar Jawa Timur misalnya, maka untuk satu kursi anggota DPD dibutuhkan dukungan 5,5 juta pemilih, sedangkan untuk menjadi anggota DPR, satu kursi jabatan anggota DPR cukup dengan dukungan 550 ribu pemilih. Calon anggota DPD dari setiap Provinsi merupakan perorangan, sementara untuk anggota DPR peserta pemilu lewat partai politik. Dengan demikian untuk menjadi seorang anggota DPD sangat sulit, tapi jika telah berhasil kewenanganya sangat sedikit atau terbatas.

\section{Presiden}

Pasca amandemen UUD 1945, sesuai dengan ketentuan pasal-pasal yang mengatur tentang kewenangan dan kekuasaan seorang Presiden sudah ada pembatasan. Pembatasan ini didasarkan atas pengalaman sejarah 
dimana kekuasaan lembaga kepresidenan sangat besar dan dominan, sehingga seringkali kekuasaan yang besar itu rawan untuk disalahgunakan seperti yang pernah terjadi pada rezim pemerinatahan Orda Lama dan Orda Baru. Secara rinci kekusaan dan kewengannya setelah amandemen UUD 1945 adalah :

a. Membatasi beberapa kekuasaan Presiden dengan merubah tata cara pemilihan dan pemberhentaian Presiden dalam masa jabatannya serta memperkuat sistim pemerintahan Presidensial;

b. Kekuasaan Presiden dalam bidang Legislasi, dialihkan ke DPR;

c. Membatasi masa jabatan Presiden menjadi hanya dua priode saja;

d. Kewenangan Presiden dalam mengangkat duta dan menerima duta negara lain harus memperhatikan pertimbangan DPR, meskipun hal ini tidak mutlak dalam pelaksanaannya;

e. Kewenangan memberikan grasi, manesti, abolisi dan rehabilitasi diperlukan pertimbangan DPR;

f. Memperbaiki syarat-syarat dan mekanisme penetapan calon Presiden dan Wakil Presiden dan pemilihan dilakukan secara langsung oleh rakyat melalui pemilihan umum, demikian juga halnya dengan tata cara pemberhentian Presiden dalam masa jabatannya.

\section{Mahkamah Agung}

Mahkamah Agung sebagai lembaga negara yang menjalankan kekuasaan kehakiman yaitu merupakan kekuasaan untuk menyelenggarakan peradilan untuk menegakkan hukum dan keadilan ( Pasal 24 ayat ( 1 )

UUD 1945 hasil amandemen. Mahkamah Agung mempunyai kewenangan untuk mengadili pada tingkat kasasi, menguji peraturan perundang-undangan dibawah UUD dan kewenangan lain yang diberikan oleh Undang-Undang.

Selain itu Mahkamah Agung juga mempunyai beberapa kewenangan antara lain :

1. Mengadili pada tingkat kasasi;

2. Menguji peraturan perundang-undangan dibawah undang-undang;

3. Melaksanakan wewenang lainnya yang diberikan oleh undang-undang.

\section{Mahkamah Konstitusi}

Kelahiran lembaga Mahkamah Konstitusi di Indnesia, merupakan fenomena baru dalam sistim ketatanegaraan Indonesia. Beberapa negara besar di dunia yang sudah mapan tidak mengenal Mahkamah Konstitusi yang berdiri sendiri seperti Indonesia. Mahkamah Konstitusi akan bertugas sebagai Penjaga Konstitusi. Mahkamah Konstitusi merupakan salah satu pelaku kekuasaan kehakiman yang mempunyai peran penting dalam upaya menegakkan kostitusi dan prinsip negara hukum sesuai tugas pokok, fungsi dan kewenangannya yang ditetapkan dalam UUD 1945. Mahkamah Konstitusi dalam fungsinya untuk menjaga konstitusi dilengkapi dengan 9 orang hakim, yang diajukan oleh 3 lembaga negara yaitu Presiden 3 orang, Mahkamah Agung 3 orang dan DPR 3 orang calon hakim agung.

\section{Badan Pemeriksa Keuangan}

Badan Pemeriksa Keuangan diatur dalam Bab tersendiri dalam UUD 1945 pasca amandemen, hal ini dimakdukan agar BPK yang bebas dan mandiri dalam melakukan pemeriksaan pengeluaran dan tanggungjawab keuangan negara.dapat dilakukan secara optimal. Dengan demikian diharapkan akan meningkatkan transparansi dan akuntabilitas pertanggunjawaban keuangan negara. Terkait dengan pemeriksaan keuangan negara, ditegaskan BPK juga berwenang memeriksa APBD meskipun daerah itu sudah otonomi. Untuk memperkuat lembaga BPK maka disetiap Provinsi ada Perwakilan BPK sebagaimana ditentukan dalam Pasal 23 C ayat ( 1 ) UUD 1945 pasca amandeemen.

\section{Hubungan Kerja Antar Lembaga Negara Berdasarkan UUD 1945 Pasca Amendemen}

\section{Hubungan antar lembaga negara dalam bidang pemerintahan.}

Pemerintahan Negara Republik Indonesia berdasarkan UUD 1945 dikatakan menganut sistim presidensiil, akan tetapi sifatnya tidak murni, karena masih bercampur aduk dengan elemen sistim parlementer. Perkembangan praktik ketatanegaraan Indonesia selama ini selalu dirasakan adanya kelemahan dalam praktik penyelenggaraan sistim pemerintahan. Para pakar tata negara cendrung menyebut sistim pemerintahan yang dianut disebut quasi presidensiil atau sistim campuran dalam konotasi negative, karena banyak mengandung distorsi bila dikaitkan dengan sistim demokrasi yang mempersyaratkan adanya hubungan cheks and balances yang lebih efektif antar lembaga negara. Kelemahan-kelemahan bawaan alam 
dari sistim presidensiil itu, adanya kecendrungan terlalu kuatnya otoritas dan konsentrasi kekuasaan ditangan Presiden. Beberapa jabatan public meskipun itu masuk dalam ranah kekuasaan ekskutif pengangkatan dan pemberhentianya harus mempertimbangkan pendapat DPR. Seperti misalnya pengangkatan Gubernur BI, Kapolri, Panglima TNI.

Dalam sistim cheks and balances antara Presiden, DPR, DPD, MA, MK, BPK mempunyai kedudukan yang sederajat, tapi dalam menjalankan tugas pokok dan fungsinya saling mengendalikan. Antara lembaga Kpresidenan dan Parlemen memiliki fungsi Co-Administraction artinya dalam rangka pengangkatan dan pemberhentian pejabat public antara Presiden dan Parlemen bisa mengembangkan fungsi CoAdministraction dalam artian pelaksanaan tugas pemerintahan bersama. Hal ini dewasa ini banyak dikembangkan dibeberapa negara dimana Exskutif mengajak parlemen dalam perundingan resmi untuk suatu perundingan dengan negara lain. Hubungan kelembagaan antara DPR dan Presiden dikenal dengan istilah "nebengeornet" atau hubungan hozontal atau selevel. Kedepan dalam rangka memperbaiki dan meningkatkan sistim bicameral yang lebih baik tiga lembaga negara yaitu Persiden, DPR dan DPD diusulkan memiliki hak veto, sehingga proses pelaksanaan cheks and balances, hak veto atas suatu RUU tidak saja dimiliki oleh Presiden, tapi juga oleh DPR dan DPD.

\section{Hubungan antar lembaga negara dalam Bidang Perundang-undangan.}

UUD 1945 sebelum amandemen, memberikan kekuasaan kepada Presiden untuk membuat UU, namun setelah amandemen kekuaasan membuat UU dialihkan ke DPR, tapi Presiden tetap diberikan hak mengajukan RUU kepada DPR.. Hal ini sesuai dengan ketentuan Pasal 20 ayat ( 1 ) UUD 1945 dan Pasal 5 ayat ( 1 ).

\section{Hubungan antara DPR dan DPD dalam hubungannya dengan sama-sama sebagai lembaga perawakilan.}

Keberadaan lembaga DPD sebagai lembaga baru ditingkat pusat, pada mulanya didasari oleh keinginan untuk mewujudkan sistim bicameral lembaga legislative. Anggota DPD dipilih melalui pemilihan umum, jumlahnya untuk setiap daerah sama yakni 4 orang, jumlah anggota DPD tidak boleh lebih dari 1/3 jumlah anggota DPR, Sidang DPD minimal satu kali dalam satu tahun. Pengaturan lembaga DPD berdasarkan UUD 1945 hasil amandemen, belum mencerminkan kedudukan yang seimbang, karena jumlah anggotanya lebih sedikit dibandingkan dengan jumlah anggota DPR. Demikian juga dengan kewenangan yang dimilki sangat terbatas, karena itu keberadaan lembaga DPD ini hanya sebagai sub-ordinasi dari DPR, pada hal menurut sistim bilameral mustinya kedua lembaga ini memiliki keweangan yang berimbang sehingga dapat menciptakan cheks and balances sesuai dengan apa yang diharapkan dengan dilakukannya perubahan terhadap UUD 1945.

\section{PENUTUP}

\section{Simpulan}

a. UUD 1945, telah empat kali mengalami perubahan, namun sejumlah pakar mencatat dan mengidentifikasi masih banyak titik lemahnya dan ini masih diperlukan perjuangan yang berat agar tujuan perubahan UUD 1945 itu dapat memenuhi tuntutan masyarakat, sehingga penyelenggaraan kekuasaan negara dapat mewujudkan kedaulatan rakyat yang dicita-citakan

b. Tentang Sistim perwakilan di parlemen, masih jauh dari harapan. Karena kelahiran lembaga DPD yang diperjuangkan agar lembaga legislasi bisa menganut dua kamar atau bicameral, ternyata tidak mudah untuk dicapai, karena masih banyak kendalanya. Kewenangan sangat sidkit, dan kedudukan DPD sangat lemah berhadapan dengan DPR. Demikian juga dengan kewenagan MPR masih kabur, tetang keberadaannya sebagai lembaga perwakilan, tapi anggota adalah kebanyakan anggota DPR dan DPD;

c. Tentang Sistim pemerintahan presidensiil dalam situasi banyak partai politik, menyebabkan akan menjadikan pemerintah kurang efektif dalam menjalankan tugas pokok dan fungsinya, apalagi kalau Presidennya tetap berstatus sebagai anggota atau petugas partai.

d. Dalam tugas-tugas Yudikatif pasti ada tugas dan fungsi yang duplikasi dan tumpang tindih, karena ada tiga lembaga yang berperan dalam bidang yudikatif yakni MA, MK dan KY. Secara substansi memang ada perbedaan tugas dan fungsinya, tapi nomenklaturnya satu yaitu Yudikatif. Antara MK dan KY atau MA, jika ditelusuri banyak pertentangan dalam menjalankan tugas dan fungsinya. Sebagai contoh : Apakah KY bisa mengawasai Hakim Agung yang ada di MK atau MA. Hal sempat ramai dibicarkan public. 
e. Sistim desentralisasi yang dominan melahirkan sikap feodalime dikalangan pejabat di daerah, Sistim otonomi daerah sering terjadi tarik ulur antara pemerintah Pusat dengan pemerintah daerah. Sebagai dampak negatifnya Tugas-tugas pemerintah pusat menjadi tidak efektif, karena daerah minta kewenagan yang lebih, sementara pemrintah Provinsi seringkali dilangkahi oleh pemerintah Kabupaten/ Kota, karena ia merasa bahwa otonomi itu ada di Kabupaten dan Kota.

\section{Saran-Saran}

a. Mengubah UUD seharusnya dilakukan dengan mengingat bahwa UUD adalah merupakan seperangkat ketentuan hukum yang membentuk suatu sistem. Oleh karena itu dengan ditetapkannya perubahan ketentuan UUD tersebut tidak menimbulkan pertanyaan yang menyangkut hubungan kekuasaan antar lembaga negara antara yang satu dengan yang lainnya seperti sekarang ini. Contohnya antara DPR dengan DPD justru memuculkan masalah karena tidak ada keseimbangan dalam pembagian kewenangan. Jika lembaga DPD masih dianggap perlu untuk dipertahankan, maka kewenangan dan kewajibannya diperbesar. Sekarang ini DPD dengan kewenagan yang sanagat terbatas, tapi memproleh perlakuan protokoler setingat dengan DPR, sehingga hal ini menjadi aneh tapi nyata di Indonesia.

b. Dalam upaya menyempurnakan UUD 1945 supaya menghasilkan sebuah UUD yang mendekati edeal maka harus dipertimbangkan Pertama : Lembaga yang diserahi tugas untuk menyusun perubahan UUD harus melibatkan komisi negara yang professional, independen, non partisan, serta melibatkan masyarakat untuk mewujudkan UUD yang pro rakyat ( the people constitution ); Kedua : bahan refrensi untuk melakukan pernyempurnaan UUD 1945, Hasil Karya Komisi yang telah bekerja selama tujuh bulan berdasarkan mandat Tap MPR No.1/MPR/2002 Jo. Keputusan MPR No.4/ MPR/ 2003, perlu dijadikan salah satu refrensi. Ketiga : Kontribusi Pemikiran Tim Kecil Pokja Amandemen UUD 1945 Forum Rektor simpul UBAYA tanggal 26 Januari 2007.

c. Sistim pemerintahan Presidensiil dalam UUD 1945, belum mendukung kofigurasi sistim politiknya. Salah satu ciri penting dari prinsip pemerintahan presidensiil adalah tidak ada ketergantungan presiden secara dominan dalam penyusunan kabinet atau mengangkat para menteri sebagai pembantunya, sehingga pengangkatan menteri itu seharusnya sungguh-sungguh menjadi hak prerogative Presiden, Namun fakta menunjukkan bahwa rencana kebijakan presiden terhadap hal ini sangat dipengaruhi oleh elit partai politik di DPR. Dan jika Presiden itu berasal dari anggota sebuah partai maka Presiden itu, harus terlepas dari partai pengusungnya dan Presiden itu bukan petugas partai, tapi adalah Pemimpin Negara dan Presiden seluruh Rakyat Indonesia secara total.

d. Reformasi Sistim Kepartaian. Era reformasi keran politik dibuka lebar, sehingga semua orang dijamin kebebasannya oleh konstitusi, termasuk setiap orang berhak mendidrikan partai, sehingga berkembang menjadi sistim politik atau multy party system. Jika jumlah partai tidak dibatasi, jumlahnya terlalu banyak, akan menurunkan citra partai itu sendiri dimata rakyat, Jika legitimasi partai dimata rakyat jelek, maka citra demokrasi di mata rakyat akan menjadi rusak. Maka Demi demokrasi, pemerintah harus membuat kebijakan yang tegas untuk membatasi jumlah partai politik, dengan cara-cara yang obyektif dan alamiah. Jika jumlah partai sedikit tapi berkualitas, maka stabilitas pemerintahan dan penyelenngaraan kekuasaan negara akan lebih efektif, sehingga akan mempercepat pencapaian tujuan bernegara yaitu mewujudkan masyarakat yang sejahtera, adil dan makmur. 


\section{DAFTAR PUSTAKA}

Alifuddin, Moh. 2012. Berdemokrasi Panduan Praktis Prilaku Demokrasi, Cetakan ke 1. Magnascript Publishing, Jakarta

A. Mukti Arsyad, 2000. Amandemen UUD 1945, Antara Teks dan ONTEKS Dalam Negara Yang Sedang Berubah, Sinar Grafika Jakaarta

Asshiddiqie, Jimly,2004. Format Kelembagaan Negara dan Pergeseran Kekuasaan Dalam UUD 1945, FH.UII, Yogyakarta.

,2005a. Hukum Tata Negara dan Pilar-Pilar Demokrasi, Cetakan ke-2. Konstitusi Press. Jakarta. ; 2005b. Mahkamah Konstitusi Dalam Sistim Ketatanegaraan Republik Indonesia

Makalah disampaikan pada Kuliah Umum di Univ.Barawijaya, Malang, 29 September 2005. 2006a, Konstitusi dan Konstitutusionalime Indonesia, Kosntitusi Press Jakarta.

2006b, Perkembangan dan Konsolidasi Lembaga Negara Pasca Reformasi, Sekretariat Jendral dan Kepanitraan Mahkamah Konstitusi RI. Jakarta

Ghoffar, Abdul. 1999. Perbandingan Kekuasaan Presiden Indonesia setelah Perubahan UUD 1945, Dengan Delapan Negara Maju. Ed.1. Cetakan ke-1. Kencana Prenada Media Group, Jakarta.

Philipus M. Hajon, 1992. Lembaga Tertinggi dan Tinggi Negara Menurut UUD 1945, suatu analisa Hukum, , PT Bina Ilmu, Suraabaya

Indra, Muhammad Ridwan, 1998. Dalam UUD 1945 Kekuasaan Exskutif Lebih Menonjol ( Exskutif Havy ) Haji Masabung Jakarta.

Isra, Saldi, 2002. Kosntitusi Baru Melalui Konstitusi, dalam Jurnal Analisis CSIS, Tahun XXXI/Nomor 2.

; Dewan Perwakilan Derah Antara Keterbatasan dan Akuntabilitas; http://www.Saldiisra.web.id.( akses 6 Maret 2019, 19.30 wita.

; Amandemen Lembaga Legislatif dan Ekskutif : Prosfek dan Tantangan, Jurnal UNISIA UII, Yogyakarta. Edisi 48, Tahun 2003. ( Makalah disampaikan dalam diskusi terbatas dengan thema Eksistensi Sistim Kelembagaan Negara Pasca Amandemen UUD 1945, yang diselenggarakan oleh Konsursium Reformasi Hukum Nasional, di Jakarta, September 2004 ).

Mahfud MD, Moh., 2000. Demokrasi dan Kosntitusi Indonesia, Studi tentang Intraksi Politik dan kehidupan Ketatanegaraan, Rineka Cipta. Jakarta

Manan, Bagir, 2003. DPR,DPD dan MPR Dalam UUD Baru, FH.UII Press. Yogyakarta

Marhall, Geoffrey, 1971, Constitutional Theory, London : Oxord University Press.

Montesquie, 1993. Membatasi Kekuasaan; Telaah Mengenai Jiwa UUD, Terjemahan.J.R. Sunaryo, Gramedia Pustaka Utama, Jakarta

Mahendra, Yusril,1983. Tentang Lembaga-Lembaga Negara Menurut UUD 1945, Citra Aditya Bakti, Bandung

1996. Dinamika Tatanegara Indonesia, Kompilasi Aktual Masalah Konstitusi DPR dan Sistem Kepartaian, Gema Insani Press, Jakarta

Siahaan, Pataniari. 2012. Politik Hukum Pembentukan UU pasca Amandemen UUD 1945. Cetakan ke-1, Kosntitusi Press. Jakarta

Suny, Ismail. 1986. Pergeseran Kekuasaan Exskutif. Cetakan ke-6. Aksara Baru. Jakarta

Triwulan Tutik, Titik. 2008. Pokok-Pokok Hukum Tata Negara Indonesia, Pasca Amandemen UUD 1945. Cetakan ke-1. Cerdas Pustaka. Surabaya

Teguh Satya Bhakti, 2009. Pola Hubungan Presiden dan DPR Menurut Perubahan UUD 1945, dalam Jurnal Konstitusi, Vo.6 No.4 Nopember 2009.

\section{Undang-Undang}

UUD 1945 Sebelum Perubahan;

UUD 1945 Pasca Perubahan (Amandemen )

UU No. 24 Tahun 2003 Tentang Mahkamah Konstitusi.

UU No. 22 Tahun 2004 Tentang Komisi Yudisial. 